\title{
ENSURING RESPECT FOR HUMAN RIGHTS AND FREEDOMS IN THE CONTEXT OF STATES' MEASURES INTRODUCTION TO COMBAT THE COVID-19 PANDEMIC: EUROPEAN EXPERIENCE
}

DOI: 10.36740/WLek202012212

\author{
Viktor V. Horodovenko ${ }^{1}$, Larysa G. Udovyka', Hanna 0. Dichko ${ }^{2}$ \\ 'ZAPORIZHZHIA NATIONAL UNIVERSITY, ZAPORIZHZHIA, UKRAINE \\ 2ZAPORIZHZHIA STATE MEDICAL UNIVERSITY, ZAPORIZHZHIA, UKRAINE
}

\begin{abstract}
The aim: To suggest the ways and means for ensuring respect for human rights and freedoms in the context of introduction of states' measures to combat the COVID-19 pandemic based on the generalization of European experience and systematization of recommendations of international and European institutions.

Materials and methods: In thise research we applied a complex of philosophical and ideological approaches, general scientific and special methods of scientific cognition, in particular civilizational and axiological approaches as well as dialectical, comparative legal and statistical methods.

The empirical basis of the study is represented by the statistical data of the healthcare sector of European countries, generalization of the practice of countering the pandemic spread. In this study we used international and European regulatory legal acts and documents in the field of human rights, national legislations of foreign countries.

Conclusions: Derogation from the provisions of the European Convention on Human Rights in the context of introduction of measures to combat the COVID-19 pandemic is a common problem for European countries, which requires emergency measures introduction by the governments of these countries; the measures introduced should be legal, necessary, non-discriminatory, with a certain specific focus and duration; ensuring respect for human rights and freedoms requires deliberate, timely and effective legal, organizational forms and methods of states' activities and international cooperation.
\end{abstract}

KEY WORDS: respect for human rights, international legal acts, national legislation, COVID-19 pandemic, human rights

Wiad Lek. 2020;73(12 p. II):2773-2779

\section{INTRODUCTION}

It is indisputable that the spread of the COVID-19 pandemic worldwide has become one of the most difficult and hard-to-predict challenges of our time. The outbreak, which the World Health Organization described as a pandemic, created the global emergency unprecedented for the last century. Under such circumstances, international organizations and national governments are faced with several complex problems and tasks that require significant financial, legal, and organizational resources. The health care system of every country in the world had to meet the challenge of finding effective measures to prevent the spread of the virus, minimize the increase in morbidity, quickly identify and isolate sick people while providing them with competent high-quality care, minimizing mortality and, at the same time, ensuring availability of medical resources for patients suffering from other, more common pathologies and diseases. The economic and social problems are menacing as well, which enforces national governments to support entrepreneurship and develop social sphere in order to cover the most vulnerable society segments (unemployed, migrants, refugees, displaced persons, homeless people, etc.). The pandemic situation exacerbates the problems of public administration in all sectors and encourages national states, supranational institutions and bodies to perform effectively and efficiently, to take reasonable and coordinated actions.

The COVID-19 pandemic has affected all countries worldwide without exception, forcing their governments to take measures aimed at minimizing the spread of the virus and reducing the incidence of people's infection. The orders issued by governments of national states are characterized by various degrees of categoricity and proportionality, up to the emergency state introduction, which entails restrictions of some human and civil rights, and freedoms. Based on the fundamentality and inviolability of human rights, principles of the rule of law and democracy, international human rights bodies and institutions are directing their efforts to develop effective mechanisms of minimization of unjustified restrictions on human rights and, at the same time, to counter the spread of the pandemic.

\section{THE AIM}

To suggest the ways and means for ensuring respect for human rights and freedoms in the context of introduction of states' measures to combat the COVID-19 pandemic based on the generalization of European experience and 
systematization of recommendations of international and European institutions.

\section{MATERIALS AND METHODS}

In this research, we applied a complex of philosophical and ideological approaches, general scientific and special methods of scientific cognition, civilizational and axiological approaches as well as dialectical, comparative legal and statistical methods. Civilizational and axiological methods were used in the research process for justifying the importance of human rights, their universality and particularity; a dialectical method- when identifying the relationship between international, European and national legislations in the field of human rights; a comparative legal approach - for analysing foreign experience in ensuring respect for human rights and freedoms in the context of introduction of measures by states to combat the COVID-19 pandemic, as well as systematization, analysis, and synthesis.

The empirical basis of the study is represented by the statistical data of the healthcare sector of European countries, generalization of the practice of countering the pandemic spread. In the study, we used international and European regulatory legal acts and documents in the field of human rights, namely the Universal Declaration of Human Rights, the International Covenant on Civil and Political Rights, the International Covenant on Economic, Social and Cultural Rights, the European Convention for Protection of Human Rights and Fundamental Freedoms, the Universal Health Coverage: Moving Together to Build a Healthier World as well as national legislations of foreign countries.

\section{REVIEW AND DISCUSSION}

The fundamental international document that proclaims and enshrines inalienable human rights and freedoms is certainly the Universal Declaration of Human Rights adopted and proclaimed by the United Nations General Assembly on 10 December 1948. Article 29 of this document says that "...everyone has duties to the community in which alone the free and full development of his personality is possible. In the exercise of his rights and freedoms, everyone shall be subject only to such limitations as are determined by law solely for the purpose of securing due recognition and respect for the rights and freedoms of others and of meeting the just requirements of morality, public order and the general welfare in a democratic society" [1].

Similar provisions are included in other international standards for human rights protection. The International Covenant on Civil and Political Rights adopted by the United Nations on 16 December 1966 declares that the right to liberty of movement and freedom to choose residence (Article 12), the right to freedom of thought, conscience and religion as well as the right to freedom of expression of one's views (Articles 18-19), the right to peaceful assembly (Article 21), and the right to freedom of association with others (Article 22) may be subject to certain restrictions provided for by law that are necessary to protect national security, public order, public health or morals [2]. The International Covenant on Economic, Social and Cultural Rights adopted by the UN General Assembly on 16 December, 1966 contains similar provisions saying that the State may subject such rights only to such limitations as are determined by law only in so far as this may be compatible with the nature of these rights and solely for the purpose of promoting the general welfare in a democratic society [3].

In situation of public emergency, the States Parties to the International Covenant on Civil and Political Rights shall immediately inform the other States Parties to the Covenant through the intermediary of the Secretary-General of the United Nations, in accordance with their legal obligations. The measures, which place restrictions on exercise of human rights, shall be strictly required by the exigencies of the situation and the scale of threat, and shall not involve discrimination. This means that such restrictions on human rights shall have a specific focus and time frame, with the most lenient approach to public health to be applied.

In the European space, the main document is the European Convention for the Protection of Human Rights and Fundamental Freedoms signed on 4 November 1950 in accordance with the Universal Declaration of Human Rights in order for the member states of the Council of Europe to respect and ensure human rights and fundamental freedoms in their territories. The fundamental rights and freedoms provided for in this international treaty include: the right to life; prohibition of torture, slavery and forced labour; the right to liberty and security of person; the right to a fair trial; and the right to respect for private and family life; freedom of thought, conscience and religion, expression of views; freedom of assembly and association. Article 15 of this document contains a provision that in time of war or other public emergency threatening the life of the nation any signatory to the Convention may take measures derogating from its obligations under this Convention to the extent strictly required by the exigencies of the situation, provided that such measures are not inconsistent with its other obligations under international law [4]. The above-mentioned public emergency can be applied to harmful consequences of the COVID-19 pandemic as well. The procedure for derogating from obligations in order to narrow the scope of certain rights and freedoms involves keeping the Secretary-General of the Council of Europe informed of the measures taken and restrictions imposed. It is also necessary to indicate the time when such measures have ceased to operate, and the provisions of the Convention are being fully executed again. Emergency powers should be exercised solely for legitimate purposes in the area of public healthcare. The human right to life is not subject to narrowing or restriction, and the use of torture and slavery as well as use of legal liability and punishments in circumvention of national legislation are always unacceptable. The restrictions in order to counter pluralism of opinions and oppositional views must not be imposed as well.

Moreover, in order to achieve universal coverage of the population with health services, on 10 October 2019, the UN General Assembly adopted a high-level political declaration "Universal Health Coverage: Moving Together to 
Build a Healthier World", following its approval by world leaders in September. The declaration recognizes that health contributes to the promotion and protection of human rights and makes a commitment to covering one billion additional people by 2023 with quality essential health services, with a view to covering all people by 2030 . The declaration stresses that strong and resilient health systems, capable of reaching people in vulnerable situations, can ensure pandemic preparedness and effective responses to any outbreak [5]. Despite the fact that civil society representatives assessed the declaration ambiguously and expressed their concern that it leaves too much discretion to governments in deciding on the degree of universal health coverage referring to "nationally determined sets", "in line with national contexts and priorities", difficulties with funding, the declaration consolidated the attention and need for efforts of state governments in health systems [6].

To date, 10 states of the European Union have exercised their right of derogation from the provisions of the Convention: Serbia, San Marino, Romania, the Republic of Moldova, North Macedonia, Latvia, Georgia, Estonia, Armenia and Albania [7]. These states are obliged to inform the population about emergency measures, the territory of their application and the time frame for their introduction and extension. Response measures should be taken in accordance with the needs that arise at different stages of the crisis situation caused by the pandemic. The states should update this information regularly and make it widely available. Also, when the epidemic situation has improved, as soon as it is feasible, the national governments should ensure that citizens return to life as normal.

Summarizing the current experience of the measures implementation by the governments of European countries to halt the pandemic spread proves that the following human rights and freedoms are among most restrictive: the right to liberty (treatment of COVID-19 patients in isolation); the right to freedom of movement (border closures, introduction of a state of emergency, restrictions on transport services, creation of quarantine zones, control over person's movement outside his residence); the right to freedom of peaceful assembly (the obligation to maintain social distancing and self-isolation regime, prohibition of holding mass events); the right to healthcare (cancellation of planned operations and medical interventions in the event of non-urgency for the patient, difficult access to healthcare due to overloaded healthcare facilities); the right to education (educational institutions' work in remote mode can complicate the access of pupils and students to educational services); the right to freedom of religion (prohibition of religious events and restriction on religious rites); the right to business activities (temporary suspension of work of entertainment and catering facilities, overall difficulties faced by entrepreneurs during the pandemic).

Having analysed the statistics of the COVID-19 incidence, we identified the "record holding" countries within the European Union. The situation is constantly changing but in general the highest number of confirmed cases of infection is observed in the following countries: Spain,
France, Italy and Germany. The United Kingdom is also on the list; it is no longer part of the EU but is included in the European statistical reports [8]. Malta, Iceland, Latvia, Cyprus and Liechtenstein enjoy the lowest figures of registered cases, which is due to the territorial remoteness of these states and small population numbers. The measures taken by the governments of these countries to restrict and halt the spread of the COVID-19 pandemic are stipulated by many factors, namely economic, legal, political and social ones. The thing they have in common is the need to strike a balance between public safety and human rights.

The process of such a complex task implementation has different characteristics in each country. Thus, Spain is currently introducing quarantine measures in the entire metropolitan region due to an increase in the incidence. In Madrid and 9 surrounding cities, the movement of citizens is restricted and control over compliance with the quarantine restrictions is being strengthened. Only those who have a valid reason (a trip to work, hospital or school, shopping, etc.) can enter this zone and leave it. The number of guests in hotels and visitors in public catering facilities cannot exceed $50 \%$ of the maximum capacity. The regulations provide for the penalties from $€ 100$ up to $€ 30,000$ for quarantine restrictions violation; resistance and disobedience to law enforcement officers in an emergency situation are also punishable by penalties of up to $€ 600$ thousand- or one-year's imprisonment [9]. The Spanish police are authorised to check the identity of persons in the street and find out the purpose of their movement. Quarantine measures are not unanimously supported by the population; there are protests demanding to ease the restrictions. Also, the government is allocating funds to support entrepreneurship (€200 billion) [10].

Italy was the country that suffered most from the COVID-19 in the spring of 2020; therefore, the measures to fight off the pandemic are more drastic and applicable in all spheres of life. The government appointed a special commissioner for emergency response to counter the spread of the pandemic, and the emergency state was introduced on the territory of the country. In the adopted Decree on the measures to combat the pandemic, it is stipulated that the state of emergency in Italy gives special powers to governors. In other words, local authorities will be able to create "red zones" or isolation areas on the territories of the COVID-19 outbreak. Wearing a mask and social distancing are mandatory - the Italian population is responsible for protecting against infection by meeting these requirements. Quarantine violators are subject to a fine of $€ 206$ - or three-months' imprisonment. The strict general quarantine lasted in Italy from the beginning of March to the beginning of May and was characterized by a ban on entry for foreigners, restrictions on movement between settlements, closure of educational and entertainment venues, and a ban on mass events such as weddings and funerals. Since then, such strict quarantine restrictions have been relaxed and sometimes introduced locally. To maintain a stable economic situation, the government has allocated extra $€ 25$ billion [11]. 
In France, no strict restrictions have been imposed since the outbreak of the COVID-19 pandemic. However, with an increased incidence of the virus, the restrictions were imposed on mass events, and gatherings of more than 10 people were banned. Public facilities such as bars, swimming pools and coffee shops were closed. There is a restriction on entry into the territory of the country of persons who are not citizens of the European Union member states. The French government has provided a $€ 100$ billion stimulus package to boost the economy affected by the global healthcare crisis. As well, the authorities have provided a $€ 207$ million stimulus package for aid during the COVID-19 outbreak to boost the economy affected by the global health crisis [12].

Among other European countries, Germany is quite successful in countering the spread of the COVID-19 virus, which is proved by the emergency measures taken by the government [13]. In the world ranking of the safest countries, Germany ranks second after Israel, according to the results of the London study conducted by experts of the Deep Knowledge Group Foundation [14]. This result is associated with a high-quality organization of response in the healthcare system. German hospitals have qualified staff and enough beds to receive patients, and if the disease is suspected, COVID-19 testing is carried out promptly. The state did not impose a strict quarantine, but entertainment and sports facilities, as well as educational institutions, were closed for some time. Religious rites were banned. Despite the threat of infection, local elections were held in Bavaria, providing all citizens with disinfection products. Violation of the quarantine rules is punishable by a penalty of up to $€ 450$ thousand or imprisonment of up to 2 years. The German Chancellor Angela Merkel is engaged in supporting business and announced the allocation of $€ 550$ billion for government loans.

The situation analysis and assessment of measures to counteract the pandemic spread in Germany shows that the government has taken a fairly objective, balanced and timely approach to the application of comprehensive measures, making the escalation of the epidemiological situation impossible. An unprecedented package of support for business activity and social assistance to citizens was also aimed at ensuring respect for human rights and freedoms when the state introduced the measures to combat the pandemic.

The UK also introduced the restrictive measures designed to counteract an increase in the number of COVID-19 patients. The first restriction was the introduction of self-isolation for the most vulnerable population group - people of the age group over 70. All other citizens were advised to reduce the number of social contacts and, if possible, telecommute. "The government's strategy for fighting coronavirus is aimed at achieving 'herd immunity' so that the health system can withstand the pressure" [15]. For violators of the established requirements and restrictions, there are significant penalties - from $£ 200$ for individuals for non-wearing a mask to $£ 10$ thousand for violations by legal entities. The compliance with the requirements will be checked not only by the police with an increased number of patrols, but also by the military forces, who will be involved in security measures. Currently, the opening hours of entertainment and public catering facilities are limited, with social distance between their visitors to be observed. Mass events are prohibited in the country and there are restrictions on the movement of public transport. Local elections, which were supposed to be held in May 2020, were postponed to May 2021. The British government also promised to allocate $£ 330$ billion to support businesses - these funds will be used to support the most vulnerable categories of the population and self-employed, whose incomes may decrease. $£ 1.3$ billion have already been allocated for the distribution of free personal protective equipment to healthcare and social services, public pharmacies and public sector organizations [16]. It is planned to allocate one-time grants of up to $£ 25$ thousand to entrepreneurs engaged in economic activities in the entertainment and catering sectors in order to prevent their bankruptcy. For common people experiencing financial difficulties, there is also a benefit - a three-month deferral of payment on mortgage loans. It should be noted that in this country, state subsidies are allocated to the private sector and through the social security system for the first time.

In the field of ensuring human rights in the UK, human rights defenders and scientists express concern and call for countering domestic violence, which has increased significantly: "Given the rise in domestic abuse during the pandemic, the UK, Scottish and Welsh Governments should ensure that survivors of domestic abuse and other forms of violence against women and girls receive appropriate protection and support, regardless of immigration status. They should also ensure that services are adequately funded and supported to address all forms of abuse, both during and after the coronavirus pandemic" [17].

The analysis of the UK's experience in fighting COVID-19 shows that the measures to counteract the pandemic spread are less effective due to several factors, namely: late response; a low level of citizens' responsibility; insufficient provision of medical equipment; limited statistical data on patients.

International organizations support the introduction of restrictive measures, as without them it will not be possible to reduce the COVID-19 incidence. They give recommendations with regard to reduction of the traumatic impact on human rights and freedoms and ensuring the population's interests during implementation of such restrictions. The United Nations emphasizes on the following actions: ensuring maximum accessibility of healthcare for every person; emergency measures introduction, including a state of emergency, should be legal, necessary and non-discriminatory, with a certain specific focus and duration, applied in the least intrusive way possible for the population; maintaining jobs, wages and housing through targeted economic programs; provision of paid medical certificates and unemployment benefits; support for employers and entrepreneurship; counteraction to corruption risks and ensuring free dissemination of information; combating dis- 
crimination; countering domestic abuse [18]. It is proposed to take measures to ensure universalization of healthcare, cooperate in the development of vaccines and treatment procedures as well as to accelerate the trade and transfer of necessary medical supplies and equipment, including personal protective equipment for health-care providers who are primarily facing infection.

The World Health Organization also issues recommendations related to the observance of human rights. In particular, attention is focused on the following: countering stigmatizing and discriminatory behaviour and practices; supporting gender equality and preventing violence against women; supporting vulnerable segments of the population (namely, disabled, homeless people, refugees, migrants and people in detention); respect for people's rights in accordance with international standards during introduction of quarantine or restrictive measures; solving the problem of shortage of materials and equipment for patients' treatment; providing international assistance and cooperation. It is noted that the $\mathrm{WHO}$ plays a crucial role in supporting member states so that they meet the challenges of our time and develop an integrated approach to the COVID-19 [19]. The recognition of human rights as an integral part of a quality health system not only will ensure the ethics of restrictions for the population, but also create the basis for response to possible healthcare crises in the future.

The Council of Europe has also issued the guidance presented in the form of toolkit "Respecting democracy, rule of law and human rights in the framework of the COVID-19 sanitary crisis" [20]. It says that the derogation from the provisions of the European Convention on human rights will be assessed by the European Court of Human Rights. Emphasis is placed on the following provisions: ensuring the right to life (availability of medical procedures and medicines, especially for patients of vulnerable groups, such as people with disabilities or elderly persons); the right to liberty and security (strict sanctions for violating anti-epidemic measures should only be imposed in accordance with the regulated procedures, it is necessary to maintain a balance between coercion and prevention); development of effective counteraction to crime and protection of victims of crime (in the context of the pandemic, such offenses as domestic abuse, human trafficking and fraud have become more relevant); confidentiality and data protection (through a widespread use of electronic resources). It is noted that all the Council of Europe institutions are mobilised and will spare no effort to use tools and resources to exchange information, good practices and experience gained from all stakeholders, including authorities, civil society and citizens in order to find common responses to the challenges posed by the pandemic. The Council of Europe will make every effort to assist its member states during the current crisis and to overcome its consequences.

In the context of the pandemic spread and introduction of quarantine measures, despite the differences in the health systems of the countries, measures introduced by the governments, different economic resources, there are similar problems arising in the field of human rights and their provision, since "the violations we are now observing, including discriminatory policies and disturbing discussions about medical rationing and "rejection" or sacrifice of the elderly for the economy sake contradict the foundations of human rights that recognize the equality and dignity of all people" [21]. Scientists from different countries, experts, politicians and officials pay special attention to problems of security of certain citizen categories (persons obliged to contact a large number of people [22], children, women, elderly persons, convicts, refugees and migrants), mental health of the population, justice, anti-corruption in the healthcare sector. We should consider the warning by Joseph Stiglitz, Professor of Columbia University and Nobel Prize winner in economics, who emphasises on the fact that "COVID-19 has not been an equal opportunity virus: it goes after people in poor health and those whose daily lives expose them to greater contact with others. And this means it goes disproportionately after the poor, especially in poor countries and in advanced economies like the United States where access to health care is not guaranteed" [23, p. 19]. That is why ensuring human rights requires governments to develop and implement national strategies to counter the spread of the pandemic in a timely manner, considering the unequal opportunities of their citizens. In the international context, the spread of the pandemic causes, among other things, an aggravation of inequality between countries, since less developed countries do not have enough resources to overcome the economic consequences of the pandemic.

Summarizing and systematizing the provisions set out in the UN, CoE and WHO program documents, we determined the following important provisions and recommendations of international and European institutions for ensuring human rights in the context of countering the spread of the COVID-19 pandemic:

- freedom of expression and access to information (the state should provide its citizens with access to statistical information about the state of morbidity and at the same time refute false information about the methods of treatment and prevention);

- ensuring maximum access to health resources (especially for vulnerable groups - elderly persons and people with disabilities, people with low incomes);

- ensuring compliance of restrictive measures with inalienable human rights (restrictions for reasons of public health or a state of emergency in the country must comply with the regulatory legal acts, be necessary and proportionate; the sanctions must have a certain appeal procedure);

- creating the safest working conditions possible for healthcare professionals and providing them with necessary means to perform their duties effectively;

- providing economic support (subsidies and benefits) for persons suffering losses due to restrictive measures (both legal entities and entrepreneurs as well as individuals - migrants, low-income and unemployed persons);

- combating discrimination and violence based on race, age, gender (through supportive measures, educational activities); 
- ensuring access to education (introduction of distance technologies);

- ensuring international cooperation and effective work of supranational institutions both to disseminate medical information, develop vaccination, new treatment methods and to provide economic and organizational support for the measures to combat the pandemic consequences.

It is also necessary to consider the fact that the national legislations of European countries guarantee human rights and their judicial protection, including applying to the European Court of Human Rights. Scholars have repeatedly emphasized that violation of human rights in the context of introducing measures by states to combat the COVID-19 pandemic can expose national states to the risk of numerous appeals from citizens to the ECHR and corresponding legal consequences [24, 25]. According to Dainius Pūras, “...the COVID-19 crisis cannot be resolved through public health and emergency measures alone; all other human rights must also be covered. The global spread of COVID-19 and the impact of measures to curb it clearly demonstrate the interdependence, interconnectedness and indivisibility of all human rights" [26].

\section{CONCLUSION}

Generalized foreign experience in ensuring human rights and freedoms in the context of introduction of states' measures to combat the COVID-19 pandemic and recommendations of international organizations (UNO, CoU, WHO) provide grounds for the following conclusions: derogation from the provisions of the European Convention on Human Rights in the context of the introduction of measures to combat the COVID-19 pandemic is a common problem for European countries and requires special attention from the ECHR; implementation of emergency measures should be legal, necessary, non-discriminatory, with a certain specific focus and duration; ensuring respect for human rights and freedoms in the context of introduction of measures to combat the COVID-19 pandemic requires deliberate, reasonable, timely and effective legal, organizational (regulating, economic, monitoring) forms and methods of state activities; the first priority is to ensure the right to life (availability of medical procedures and medicines, especially for patients of vulnerable groups); the right to liberty and security (strict sanctions for violating anti-epidemic measures should only be imposed in accordance with the regulated procedures); the right to work (provides for maintaining jobs, wages, provision of paid medical certificates and unemployment benefits). In order to ensure the respect for human rights and freedoms, it is essential to provide free dissemination of information; counteraction to crime, primarily, domestic violence and protection of victims of crime; confidentiality and data protection. A complex approach to the problem of ensuring human rights in the field of European and international activities to counter the spread of the COVID-19 pandemic is of extreme importance.

\section{REFERENCES}

1. The Universal Declaration of Human Rights Available from: https:// www.un.org/en/universal-declaration-human-rights/. [reviewed 2020.08.14].

2. International Covenant on Civil and Political Rights Available from: https://www.ohchr.org/en/professionalinterest/pages/ccpr.aspx. [reviewed 2020.08.14].

3. International Covenant on Economic, Social and Cultural Rights Available from: https://www.ohchr.org/en/professionalinterest/pages/cescr. aspx. [reviewed 2020.08.14].

4. European Convention on Human Rights Available from: https://www. echr.coe.int/documents/convention_eng.pdf. [reviewed 2020.08.14].

5. Universal health coverage: moving together to build a healthier world. Resolution adopted by the General Assembly on 100ctober 2019 Available from: https://undocs.org/en/A/RES/74/2. [reviewed 2020.08.14].

6. Dunja Mijatović. Learning from the pandemic to better fulfil the right to health Available from: https://www.coe.int/en/web/ commissioner/-/learning-from-the-pandemic-to-better-fulfil-theright-to-health?inheritRedirect=true. [reviewed 2020.08.14].

7. Notifications under Article 15 of the Convention in the context of the COVID-19 pandemic. Status as of 130 ctober 2020 - Last update Serbia Available from: https://www.coe.int/en/web/conventions/full-list/-/ conventions/webContent/62111354. [reviewed 2020.08.15].

8. COVID-19 situation update for the EU/EEA and the UK Available from: https://www.ecdc.europa.eu/en/cases-2019-ncov-eueea. [reviewed 2020.08.14].

9. .COVID-19 'Superspreaders' Will Be Fined Up To $€ 600,000$ In Andalusia. Healthplan magazine. Available from: https://www.healthplanspain. $\mathrm{com} / \mathrm{blog} / \mathrm{spain}$-news/983-covid-19-superspreaders-will-be-finedup-to-600-000-in-andalusia.html. [reviewed 2020.08.14].

10. European Commission. Spain. Details of Spain's support measures to help citizens and companies during the significant economic impact of the coronavirus pandemic Available from: https://ec.europa.eu/info/ivework-travel-eu/health/coronavirus-response/jobs-and-economy-duringcoronavirus-pandemic/state-aid-cases/spain_en. [reviewed 2020.08.14].

11. European Commission. Italy. Details of Italy's support measures to help citizens and companies during the significant economic impact of the coronavirus pandemic Available from: https://ec.europa.eu/info/livework-travel-eu/health/coronavirus-response/jobs-and-economy-duringcoronavirus-pandemic/state-aid-cases/italy_en. [reviewed 2020.08.14].

12. European Commission. France. Details of France's support measures to help citizens and companies during the significant economic impact of the coronavirus pandemic Available from: https://ec.europa.eu/info/ivework-travel-eu/health/coronavirus-response/jobs-and-economy-duringcoronavirus-pandemic/state-aid-cases/france_en. [reviewed 2020.08.16].

13. Country review. Germany's experience in fighting COVID-19 Available from:https://ach.gov.ru/upload/pdf/Germany-Covid-19.pdf. [reviewed 2020.08.14].

14. Deep Knowledge Group. Top-40 COVID-19 safety ranking Available from: https://www.dkv.global/safety-ranking. [reviewed 2020.08.14].

15. Country review.UK experienceinfighting COVID-19Availablefrom:https:// ach.gov.ru/upload/pdf/England.pdf. [reviewed 2020.08.20].

16. European Commission. United Kingdom. Details of the UK's support measures to help citizens and companies during the significant economic impact of the coronavirus pandemic Available from: https:// ec.europa.eu/info/live-work-travel-eu/health/coronavirus-response/ jobs-and-economy-during-coronavirus-pandemic/state-aid-cases/ united-kingdom_en. [reviewed 2020.08.14]. 
17. How coronavirus has affected equality and human rights. October 2020 - Is Britain Fairer? Report series. Equality and Human Rights Commission (EHRC) Available from: https://www.equalityhumanrights.com/sites/ default/files/equality_and_human_rights_commission_how_ coronavirus_has_affected_equality_and_human_rights_2020.pdf. [reviewed 2020.08.20].

18. United Nations Report. Covid-19 and human rights: we are all in this together Available from: https://www.un.org/victimsofterrorism/en/ node/5805. [reviewed 2020.08.20].

19. Addressing Human Rights as Key to the COVID-19 Response Available from: https://www.who.int/publications/i/item/addressing-humanrights-as-key-to-the-covid-19-response. [reviewed 2020.08.20].

20. Council of Europe. Respecting democracy, rule of law and human rights in the framework of the COVID-19 sanitary crisis. Available from: https://www.coe.int/en/web/congress/covid-19-toolkits. [reviewed 2020.08.14].

21. M. Fernandez and D. Montgomery "Texas tries to balance local control with the threat of the pandemic," New York Times (March 24, 2020) Available from: https://www.nytimes.com/2020/03/24/ us/coronavirus-texas-patrick-abbott.html?0p19G=0038. [reviewed 2020.08.14].

22. Tetiana L. Syroid, Lina 0. Fomina, Oleksandr A. Havrylenko Ensuring the Right to Health of Staff of the United Nations. Wiadomości Lekarskie. 2020; 73 (9 p. 2) : 2044-2048. Available from:https://wiadlek.pl/ wp-content/uploads/archive/2020/WLek202009228.pdf [reviewed 2020.08.14].

23. Stiglitz J. Conquering the Great Divide. IMF Finance \& Development. 2020;4:17-19 Available from: https://www.imf.org/external/russian/ pubs/ft/fandd/2020/09/pdf/COVID19-and-global-inequality-josephstiglitz.pdf. [reviewed 2020.08.14].

24. ViktorV. Horodovenko, Vitalii M. Pashkov, Larysa G. Udovyka Protection of patients' rights in the European Court of Human Rights. Wiadomosci lekarskie. 2018; 71 (6) : 1200-1206 Available from: https://www. researchgate.net/publication/327974885_Protection_of_patients'_ rights_in_the_european_court_of_human_rights. [reviewed 2020.08.20].

25. Viktor V. Horodovenko, Vitalii M. Pashkov, Larysa G. Udovyka International legal instruments in the field of bioethics and their impact on protection of human rights. Wiadomosci lekarskie. 2020; 73 (7) : 1554-1560 doi: 10.36740/WLek202007144.
26. Dainius Pūras. Public Health Policy Shapes COVID-19Impact: UN Expert's Final Report Available from: https://www.hhrjournal.org/2020/10/ public-health-policy-shapes-covid-19-impact-un-experts-finalreport/. [reviewed 2020.08.15].

The study was accomplished within the framework of the complex scientific project "The main directions for the improvement of the legislation of Ukraine in the context of European integration processes" (State Registration Number 0115U00710).

\section{ORCID and contributionship:}

Viktor V. Horodovenko: 0000-0001-6002-4192 A, F, E

Larysa G. Udovyka: 0000-0001-9260-4474 D, E

Hanna O. Dichko: 0000-0001-5214-7117 ${ }^{B}$

\section{Conflict of interest:}

The Authors declare no conflict of interest.

\section{CORRESPONDING AUTHOR Larysa G. Udovyka \\ Zaporizhzhia National University \\ 66 Zhukovsky str., 69600 Zaporizhzhia, Ukraine \\ tel: +380500880309 \\ e-mail: lora.znu@gmail.com}

Received: 01.09.2020

Accepted: 30.11 .2020
A - Work concept and design, B - Data collection and analysis, C - Responsibility for statistical analysis, D-Writing the article, $\mathbf{E}$-Critical review, $\mathbf{F}$ - Final approval of the article 